\title{
FIBULAE FROM SARMATIAN COMPLEXES OF THE ESAULOVSKY AKSAI ${ }^{1}$
}

\author{
Elena A. Korobkova \\ Volgograd State University, Volgograd, Russian Federation
}

\begin{abstract}
Introduction. Metal clasps for clothes, being a detail of a suit and being exposed to fashion trends, quite often changed, which makes it possible to use them as a dating material. Methods. The historical, cultural and typological methods are used in the work. Sources on the topic are represented with the reports on archaeological studies of burial mounds belonging to the Esaulovsky Aksai river basin as well as the publication of the results of archaeological research in this region and the actual fibrous material from the funds of the Volgograd Museum of Regional Studies, the State Hermitage Museum and the Astrakhan State Museum-Reserve. Analysis. The paper analyzes fibula material from Sarmatian monuments of the Esaulovsky Aksay. The main points of view on the dating of clasps in the scientific literature are presented and these data are compared in the tangible material found in the burials. Results. The time of occurrence of the fibulae found in the monuments of the Esaulovsky Aksai can be divided into two periods. Over the first period $\left(1^{\text {st }}\right.$ century $B C$ - first half of the $2^{\text {nd }}$ century $\left.A D\right)$, the range of fibulae had been wide. At this time, probably, through the urban centers of the Northern Black Sea coast, the provincial Roman clasps enter the steppe. But, despite the great variety of the types of clasps in this period, their number is small and occurs in $5 \%$ of burials. Over the second period (second half of the $2^{\text {nd }}-$ first half of the $3^{\text {rd }}$ century AD), there is an increase in the number of clasps in the Sarmatian burials with a significant reduction in assortment. At that time the clasps were represented with only two types manufactured in the cities of Bosporus and found in $26 \%$ of the burials. In connection with the events of the mid $3^{\text {rd }}$ century AD the arrival of clasps as well as other imports from the Northern Black Sea coast in the steppe of Esaulovsky Aksay stopped.

Key words: fibula, archaeological monument, Early Sarmatian Culture, Middle Sarmatian Culture, Late Sarmatian Culture, Esaulovsky Aksai.

Citation. Korobkova E.A. Fibulae from Sarmatian Complexes of the Esaulovsky Aksai. Vestnik Volgogradskogo gosudarstvennogo universiteta. Seriya 4, Istoriya. Regionovedenie. Mezhdunarodnye otnosheniya [Science Journal of Volgograd State University. History. Area Studies. International Relations], 2018, vol. 23, no. 6, pp. 44-60. (in Russian). DOI: https://doi.org/10.15688/jvolsu4.2018.6.3
\end{abstract}

УДК 930.26(470.45)

ББК 63.48(235)
Дата поступления статьи: 03.04.2018

Дата принятия статьи: 04.09.2018

\section{ФИБУЛЫ ИЗ САРМАТСКИХ КОМПЛЕКСОВ ЕСАУЛОВСКОГО АКСАЯ ${ }^{1}$}

\section{Елена Алексеевна Коробкова}

Волгоградский государственный университет, г. Волгоград, Российская Федерация

\begin{abstract}
Аннотация. Металлические застежки для одежды, будучи деталью костюма и, как и он, подвергаясь веяньям моды, довольно часто видоизменялись, что дает возможность использовать их в качестве датирую$\infty$ щего материала. Время бытования фибул, обнаруженных в памятниках Есауловского Аксая, можно разделить на два периода. В первом периоде (І в. до н. э. - первая половина II в. н. э.) ассортимент фибул широк. В это время, вероятно, через городские центры Северного Причерноморья в степь поступают провинциально-римские застежки, но, несмотря на большое разнообразие типов фибул в этот период, их количество мало и встречается в 5 \% погребений. Во второй период (вторая половина II - первая половина III в. н. э.) отмечается увеличение количества фибул в сарматских погребениях при существенном снижении ассортимента. В это время фибулы представлены всего двумя типами застежек, изготавливаемыми в городах Боспора и встречающимися в 26 \% погребений этого времени. В связи с событиями середины III в. н. э. поступле() ние фибул, как и других импортов из Северного Причерноморья в степи Есауловского Аксая, прекращается.
\end{abstract}


Ключевые слова: фибула, археологический памятник, раннесарматская культура, среднесарматская культура, позднесарматская культура, Есауловский Аксай.

Цитирование. Коробкова Е. А. Фибулы из сарматских комплексов Есауловского Аксая // Вестник Волгоградского государственного университета. Серия 4, История. Регионоведение. Международные отношения. - 2018. - Т. 23, № 6. - С. 44-60. - DOI: https://doi.org/10.15688/jvolsu4.2018.6.3

Введение. Фибулы - металлические застежки для одежды, которые одновременно с утилитарными свойствами играли и роль украшения. Будучи деталью костюма и, как и он, подвергаясь веяньям моды, фибулы довольно часто видоизменялись. Небольшие размеры и простота изготовления не позволяют предполагать их долгого бытования, что дает возможность использовать фибулы в качестве хроноиндикатора.

Методы. В работе использованы историко-культурный и типологический методы.

Источниками по теме являются отчеты об археологических исследованиях курганных могильников, относящихся к бассейну реки Есауловский Аксай [16], а также публикации результатов археологических исследований этого региона и собственно фибульный материал из фондов Волгоградского областного краеведческого музея, Государственного Эрмитажа и Астраханского государственного музея-заповедника.

Исследованию фибул, их типологии и хронологии посвящено множество специальных работ. Первые труды о металлических застежках выходят в Западной Европе, где исследователи отводили им заметное место в своих типологических и хронологических построениях. Первым крупным исследованием, посвященным фибулам юга Восточной Европы, стала книга О. Альмгрена, вышедшая в 1887 г. и переизданная в 1923 г. [45]. В своей работе О. Альмгрен предложил классификацию и хронологию фибул, ставших основой для дальнейших работ археологов. Первой крупной отечественной работой стал свод фибул юга Восточной Европы II в. до н. э. - IV в. н. э., подготовленный А.К. Амброзом [3]. Предложенные в нем типология и терминология закрепились в отечественной науке и до сих пор не претерпели серьезных изменений, чего нельзя сказать о хронологии металлических застежек.

За более чем полувековой период после выхода в свет свода А.К. Амброза был на- коплен огромный материал, позволивший пересмотреть отдельные варианты, а также хронологию некоторых типов фибул. Появилась серия работ о металлических застежках отдельных регионов $[2 ; 23 ; 31 ; 37 ; 38$; и др.]. Все это привело к необходимости новой сводной работы, посвященной фибульному материалу. Таким исследованием стал труд В.В. Кропотова ${ }^{2}$, в котором автор при выделении фибульных групп, серий и вариантов стремился максимально соответствовать делению, предложенному О. Альмгреном и А.К. Амброзом, при этом уточнив хронологию фибул на основании сопоставления результатов типологического анализа, картографирования и стратиграфических наблюдений [21].

Анализ. В сарматских погребениях Есауловского Аксая фибулы - нечастая находка. Так, из более чем 500 сарматских погребений застежки были встречены в 30 комплексах и представлены 33 экземплярами. Наиболее многочисленная группа - северопричерноморские сильно профилированные фибулы, составившие почти половину всех находок. Следующей по частоте встречаемости является группа лучковых подвязных застежек. Фибулы других типов представлены отдельными экземплярами.

Самой ранней находкой металлических застежек в регионе является обнаруженная в погребении 5 кургана 33 могильника Перегрузное $[22$, с. 52 , рис. 67,8$]$ бронзовая одночленная фибула среднелатенской схемы так называемого зарубенецкого типа с треугольно расширенным концом ножки, прикрепленным к спинке, и четырехвитковой пружиной с верхней тетивой. От классических образцов этого типа фибул ее отличает короткая пружина и щиток, закрывающий лишь часть спинки фибулы. Фибула деформирована, длина ее составляет 8,5 см (рис. 1, 1 ).

Фибулы подобного типа по-разному датируются исследователями. Так, по А.К. Амброзу, она может быть отнесена к 3-му варианту среднелатенских фибул с треугольно рас- 
ширенным концом ножки. Фибулы этого варианта датируются им в пределах последней трети I в. до н. э. - начала I в. н. э. [3, с. 17]. К.В. Каспарова, предположив появление фибул этого типа от «копьевидных» образцов, распространенных на юге Балканского полуострова, отнесла наиболее ранние их экземпляры ко второй четверти II в. до н. э. [13, с. 62-63]. К копьевидным зарубенецким застежкам относят подобные фибулы Ю.П. Зайцев и В.И. Мордвинцева, датируя их на основании крымских материалов второй половиной II в. до н. э. [10, c. 181]. По типологии С.П. Пачковой фибула из погребения 5 кургана 33 могильника Перегрузное попадает в тип 3T IVa. Появление этих фибул С.П. Пачкова относит ко времени не ранее 120-116 гг. до н. э., а выход из употребления - к 60-50 гг. до н. э. [32, с 116]. В.В. Кропотов считает условным разделение на варианты фибул зарубенецкого типа, предложенное А.К. Амброзом, не играющим роли ни в эволюции застежек этого типа, ни в хронологических построениях и относит время их бытования ко второй половине II-I вв. до н. э. без «захода» в I в. н. э. При этом фибулы с четырехвитковой пружиной с верхней тетивой могут быть датированы, по его мнению, в основном второй половиной І в. до н. э. [21, с. 58].

Курган 33 Перегрузненского могильника представляет собой курган-кладбище с сооруженными в один ряд относительно одновременными захоронениями. Погребение 5 являлось основным в кургане и было совершено немногим ранее, чем большее число захоронений. С погребенным были уложены: железный кинжал с кольцевидным навершием, крупная глазчатая бусина, железные трехлопастные черешковые стрелы, лепной сосуд с «полотенчатым» орнаментом и гончарный кувшин с зооморфной ручкой. Все эти вещи совокупно с обрядом погребения позволяют отнести данное захоронение к заключительному этапу раннесарматской культуры, датирующемуся в пределах II-I вв. до н. э., что не дает возможности уточнить более узкую дату фибулы данного типа.

Воинская одночленная фибула со сплошным коротким приемником, прямым гладким корпусом и четырехвитковой пружиной с верхней тетивой обнаружена в погребении 1 кургана 6 могильника Аксай I [4, с. 97, рис. 7, 4]. Длина фибулы - 6,8 см (рис. 1, 2). Время ее бытования было определено А.К. Амброзом в пределах I в. н. э. [3, с. 25]. В дальнейшем эта дата была пересмотрена в сторону ее удревнения. К.В. Каспарова на основе зарубенецких материалов датировала воинские фибулы второй половиной - концом I в. до н. э. первой половиной I в. н. э. [12, с. 138-139]. Предложенная датировка фибул была принята исследователями с уточнениями для отдельных регионов. Так, И.В. Сергацков, соглашаясь с общей датировкой таких фибул, считал, что для нижневолжских экземпляров стоит делать акцент на первую половину І в. н. э. [33, с. 414]. В.В. Кропотов предположил, что к более ранним застежкам, датирующимся концом I в. до н. э., относятся крупные экземпляры с низким прямым корпусом, а изделия первой половины I в. н. э. отличают меньшие размеры и плавно изогнутая спинка [21, с. 62]. Еще к более раннему времени относят начало бытования подобных фибул Б.Ю. Михлин [28, с. 190-191] и Ю.П. Зайцев и В.И. Мордвинцева [10, с. 181-182], датируя их в рамках конца II - начала I в. до н. э.

В погребении 1 кургана 6 могильника Аксай I в качестве сопутствующего инвентаря были положены: кинжал с кольцевидным навершием и прямым перекрестием, гончарные кувшины, широко известные в погребениях Центрального Предкавказья, бусы, зеркало с плоским диском. Весь этот комплекс может быть датирован I в. до н. э. - серединой I в. н. э. В то же время коллективное захоронение выполнено в широкой прямоугольной яме. Подобный тип захоронения несвойственен для памятников Есауловского Аксая до рубежа эр, которые в подавляющем большинстве представлены погребениями в узких прямоугольных ямах или ямах с подбоями в курганах-кладбищах. Это дает возможность предположить, что представленный комплекс датируется началом I в. н. э.

Уникальной для Нижнего Поволжья является находка так называемой фибулье «бойев». Фибулы этого типа встречаются на территории Бельгии, Германии, Польши. Редкие экземпляры известны в западных областях распространения зарубенецкой культуры. Датируются фибулы этого типа концом I до н. э. началом I в. н. э. [3, с. $25 ; 45$, p. 8-9]. 
Бронзовая застежка с резко прогнутой дужкой и бусиной в месте прогиба, с нижней тетивой и длинным ажурным приемником обнаружена в погребении 2 кургана 51 могильника Перегрузное I [22, с. 75, рис. 111, 3]. Длина фибулы - 5,6 см (рис. 1, 3). Вещевой комплекс представлен серебряным кубком с зооморфной ручкой в виде волка, обломком плоского зеркала, железным «жезлом», большой и малой цилиндрическими курильницами, гончарным кувшином с петлевидной ручкой, имеющим прямые аналогии в Нижнедонских памятниках, бронзовым котлом с петлевидной ручкой. По совокупности всех находок погребение может быть датировано I в. н. э.

Нужно отметить, что ближайшей аналогией рассматриваемой застежки является фибула из с. Островец Ивано-Франковской области $[35$, рис. 10,17$]$. На территории юга России на настоящий момент находок фибул «бойев» нет, что ставит вопрос о путях поступления этой застежки к сарматам междуречья Волги и Дона.

Редкой находкой для региона являются шарнирные фибулы типа «Aисіssa». Застежки этого типа хорошо известны на Западе, в первую очередь в Галлии и Северной Италии. Западные образцы датируются концом І в. до н. э. (20-10 гг. до н. э.) - началом I в. н. э. [47, S. 29; 48, p. 323; 49, S. 114-115], при этом отдельные экземпляры фиксируют во второй половине I в. н. э. [48, p. 323], а в некоторых регионах империи - вплоть до начала II в. н. э. $[46$, p. 78$]$. В отечественной историографии долгое время бытовало представление о том, что фибулы из археологических комплексов на юге нашей страны одновременны застежкам этого типа на Западе и датируются первой половиной I в. н. э. [3, с. 26; 36, с. 109 ; и др.]. В ходе дальнейших исследований было высказано мнение о более позднем времени появления застежек этого типа в археологических комплексах южнорусских степей. Так, А.В. Симоненко считает, что фибулы этого типа запаздывают и появляются в Северном Причерноморье не ранее 45-49 гг. н. э. [35, c. 21]. В.В. Кропотов также считает, что фибулы типа «Aucissa» запаздывают и характерны для погребений второй половины I - начала II в. н. э. [21, с. 273], а отдельные экземп- ляры могут встречаться в погребениях II первой половины III в. н. э. [27, с. 126].

В погребальных комплексах Есауловского Аксая обнаружены две шарнирные фибулы типа «Aucissa». В погребении кургана 25 могильника Аксай II [9, с. 16, рис. 9, 13] обнаружена сильно коррозированная бронзовая шарнирная застежка в обломках. Застежка относится к типу классической «Aucissa», без надписи, с двумя глазками и следами сетчатого орнамента. Размер - 4,5-5 см (рис. 1, 4).

Вторая фибула типа «Aucissa» с массивной дуговидной спинкой, украшенной оттисками мелкозубчатого штампа, без надписи, с двумя глазками была найдена в погребении 2 кургана 8 могильника Ковалевка [8, с. 48, рис. 117]. Ось шарнира застежки выполнена из железа. Длина фибулы - 5,8 см (рис. 1, 5).

Материалы, представленные в обоих погребениях, могут быть датированы в рамках I - начала II в. н. э. без возможности сужения этой даты до полувека, что не позволяет определить время бытования фибул типа «Aucissa» в данном регионе.

Еще одной уникальной находкой для данного района является шарнирная фибулаброшь, обнаруженная в погребении кургана 1 могильника Октябрьский II [30, с. 184, рис. 2, 3]. Застежка выполнена в виде парящего голубя с округлыми отверстиями, окруженными желобками. Край хвостового оперения орнаментирован насечками. Длина - 4,1 см (рис. 1, б).

Группа шарнирных фибул в виде животных, к которым была отнесена застежка в виде летящего голубя, датирована А.К. Амброзом «в основном II в. н. э.» [3, с. 34-35]. Фибулам этого типа посвятил отдельную работу Г. Винтер. Э. Эттлингер отнесла время бытования фибул этого типа к периоду с середины I - середины II в. н. э. [47, S. 30]. Э. Риха сузил границы бытования застежек этого типа, не выводя его за пределы I в. н. э. [49, S. 198, taf. 78]. I в. н. э. датировал эту фибулу И.В. Сергацков [33, с. 416]. Д.А. Костромичёв ограничил время бытования данных фибул серединой I - рубежом III вв. н. э. [17, с. 74]. Этим же временем датируют фибулу в виде парящего голубя из могильника Старокорсуньского городища Н.Ю. Лимберис и И.И. Марченко [23, с. 226].

Вещевой материал погребения кургана 1 могильника Октябрьский II подробно рас- 
смотрен в публикации В.И. Мордвинцевой и Е.П. Мыськова [30] и в целом укладывается в рамки второй половины I - начала II в. н. э., что соотносится с общепринятой датой бытования фибул этого типа.

В единичном экземпляре встречена сильно профилированная фибула с расширенной головкой. Она была обнаружена в кургане 36 могильника Аксай II [9, с. 24, рис. 16,2$]$. Фибула имеет расширенную головку без опорной пластины, сложнопрофилированную бусину на спинке и биконическую бусину на конце приемника. Сам приемник, как и игла, обломаны, что не дает возможности судить о его форме. Длина - 7 см (рис. 1, 7). Погребение ограблено, по имеющимся вещам датировать погребение можно лишь на основании самой фибулы.

Такие фибулы известны в Дакии, где их обычно датируют второй половиной І в. н. э. [50, p. 53]. Отечественными исследователями фибулы этого типа датируются второй половиной I - началом II в. н. э. [3, с. 36-38; 21, c. 259].

Наиболее многочисленную серию составляют сильно профилированные фибулы. Производство сильно профилированных застежек было налажено на Боспоре в конце I - начале II в. н. э. по аналогии с нижнедунайскими образцами. Фибулы производились на внутренний рынок, в том числе и для восточных кочевников [3, с. 94].

Впервые этот тип фибул был выделен О. Альмгреном [45, p. 44, pic. 87], который определил тенденцию развития данного типа от вариантов с проволочной короткой спинкой к образцам с вытянутой пластинчатой спинкой. А.К. Амброз разделил фибулы этой группы на две серии по наличию или отсутствию крючка для тетивы, а их, в свою очередь, на варианты по типу бусин и длине спинки [3, с. 40-43]. Фибулы с приемником, далеко отстоящим от средней бусины, датированы им второй половиной I - первой половиной II в. н. э.; с приемником, начинающимся от средней бусины, и относительно недлинной спинкой - II в. н. э.; с длинной II - первой половиной III в. н. э. [3, с. 40-41].

Нужно отметить, что типология фибул этой серии неоднократно подвергалась пересмотру, уточнению и дополнению. А.С. Скрипкин, для того чтобы уйти от «элемента субъек- тивизма», разделил сильно профилированные фибулы на два варианта в зависимости от длины спинки. Особое внимание он уделил и форме спинки, считая, что образцы с пластинчатой спинкой «в большей степени характерны для поздних фибул этого типа» [39, с. 109-110]. На основании этой типологии им была предложена уточненная датировка сильно профилированных застежек для Нижнего Поволжья. Так, фибулы с короткой спинкой были отнесены к первой половине II в. н. э., а с длинной ко второй половине II в. н. э. [39, с. 110-113]. При этом А.С. Скрипкин особо отмечал, что в Нижнем Поволжье сильно профилированные фибулы выходят из употребления после II в. н. э. [37, с. $185 ; 39$, с. 112-113]. М.В. Кривошеев, соглашаясь с датировкой фибул 2-го варианта, предложенной А.С. Скрипкиным [20, c. 66], удревняет 1-й вариант, считая, что первые образцы застежек с короткой спинкой появляются уже в конце I в. н. э. [20, с. 64].

В.М. Косяненко, проанализировав фибульный материал из некрополя Кобяковского городища, предложила отказаться от учета пропорций корпуса, а в качестве типообразующего элемента учитывать форму спинки. На основе разработанной ей типологии фибулы с пластинчатой спинкой были отнесены ею ко второй трети I в. н. э., а фибулы с раскованной спинкой - ко II в. н. э. с возможным заходом в III в. н. э. $[18$, с. $45-49 ; 19$, с. $85-86]$. В то же время исследователь отмечает, что для более узкого датирования необходимо учитывать и расстояние от задней бусины до приемника и между средней и задней бусинами $[18$, c. 48$]$. С увеличением материала и фиксацией сочетания разнотипных фибул В.М. Косяненко пришла к выводу о возможном времени совместного бытования фибул с проволочной и пластинчатой спинкой. Время такого совместного бытования она отнесла к началу II в. н. э. [6, с. 30-32]. К этому же мнению пришли Т.А. Габуев и В.Ю. Малашев на основе данных археологических комплексов Центрального Предкавказья, датируя образцы с узкой спинкой серединой II - началом III в. н. э., a с широкой - концом II - первой половиной III в. н. э., указывая на возможную их взаимовстречаемость в конце II в. н. э. [5, с. 133-134].

М.П. Абрамова, проанализировав фибулы из Хумаринского могильника, пришла к вы- 
воду, что пропорции спинки сильно профилированных застежек Центрального Предкавказья не являются хронологическим показателем. Оба варианта встречаются в погребениях, датирующихся в рамках второй половины II - первой половины III в. н. э. [2, с. 101]. На основе находок на Южном Урале М.Г. Мошкова также считает возможным датировать сильно профилированные фибулы не только ІІ в. н. э., но и первой половиной ІІІ в. н. э. [31, с. 187]. И В.В. Кропотов считает необоснованным использование в качестве хроноиндикатора длины спинки и ее ширину и датирует фибулы этого типа II - первой половиной III в. н. э. [21, с. 229-231].

Всего на памятниках Есауловского Аксая было обнаружено 11 фибул этого типа, а также фрагмент приемника из ограбленного погребения кургана 15 могильника Перегрузное I [22, с. 28 , рис. 29,7$]$.

В Жутовском курганном могильнике было обнаружено 4 бронзовых сильно профилированных фибулы. В кургане 2 найдена застежка с короткой проволочной спинкой [40, л. 45-46]. Длина - 4,2 см (рис. 2, 1). В кургане 3 фибула имела длинную пластинчатую спинку [40, л. 47, рис. 57]. Длина - 6,3 см (рис. 2, 2). В кургане 38 - фибула с длинной проволочной спинкой [24, л. 31]. Длина - 5,6 см (рис. 2, 3). Такую же длинную проволочную спинку имела фибула из кургана 56 [24, л. 33]. Длина 6,2 см (рис. 2, 4).

В кургане 46 Чиковского могильника находилась бронзовая одночленная фибула с длинной сильно раскованной спинкой $[43$, л. 57 , рис. LIII, 5]. Длина фибулы - около 7,2 см (рис. 2, 11).

Две бронзовые одночленные фибулы с многовитковой пружиной с верхней тетивой, с крючком для тетивы и длинной пластинчатой спинкой были обнаружены в погребении 1 кургана 1 могильника Аксай I [4, с. 93, рис. 2, 5, 6]. Длина одной из них $-5,3$ см (рис. 2, 5), другой $-4,5$ см (рис. 2, б).

Еще две фибулы были обнаружены в погребении 1 кургана 21 могильника Перегрузное I $[22$, с. 35 , рис. $39,6,10]$. Одна из них железная фибула с многовитковой пружиной, проволочной спинкой, расстояние между бусинами спинки и бусиной на конце приемника равно. Длина $-6,2$ см (рис. 2, 7). Вторая брон- зовая фибула - с длинной пластинчатой спинкой. Фибула подвергалась ремонту, ее пружина и игла были сделаны из отдельного куска железной проволоки. Длина $-6,2$ см (рис. 2, 8).

В погребении 1 кургана 27 могильника Перегрузное I также обнаружены две бронзовые одночленные сильно профилированные фибулы [22, с. 42 , рис. 52, 3, 4]. Одна из них с длинной пластинчатой спинкой. Длина 6,3 см (рис. 2, 9). Другая - с проволочной спинкой, расстояние между бусинами спинки и бусиной на конце приемника равно. Длина 4,3 см (рис. 2, 10).

Погребения, из которых происходят указанные экземпляры, в большинстве своем содержат инвентарь, не имеющий оснований для узкой датировки. В рамках полувека может быть датировано лишь погребение из кургана 38 Жутовского могильника, в котором кроме фибулы, курильницы и кувшина была обнаружена гончарная миска с прямым наклоненным бортиком, украшенным желобками. Она имеет прямые аналогии в памятниках Нижнего Дона и Центрального Предкавказья, где датируется I - первой половиной II в. н. э. Если учесть, что фибулы данного типа встречаются в памятниках Нижнего Поволжья начиная со II в. н. э., то дата комплекса может быть определена в рамках первой половины II в. н. э.

В рамках II в. можно датировать также и погребение из кургана 3 Жутовского могильника, в котором в качестве сопроводительного инвентаря находились сероглиняный кувшин с высоким цилиндрическим горлом и ложновитой ручкой. Аналогичные кувшины хорошо известны в памятниках Нижнего Подонья, где датируются II в. н. э. К этому же времени можно отнести и лепной горшок с небольшим воронкообразным горлом.

Вещевой набор остальных погребений с фибулами рассматриваемого типа близок друг к другу. Они могут быть датированы в рамках II - первой половины III в. н. э. В них встречаются зеркала-подвески с колесным орнаментом и квадратом в центре, гончарные «пухлогорлые» кувшины с коленчато-изогнутой ручкой и гончарные горшки «корчаги», происходящие из центральных районов Северного Кавказа. 
Таким образом, материалы погребальных комплексов Есауловского Аксая не дают возможности уточнить временные рамки бытования различных вариантов сильно профилированных фибул. Видимо, независимо от формы спинки, эти фибулы бытовали в одно и то же время.

Сложно точно определить и верхнюю границу существования сильно профилированных фибул в регионе, так как большая часть фибул встречена в погребениях, датирующихся в рамках II - первой половины III в. н. э. Следует отметить, что подавляющее большинство аксайских погребений с этими фибулами сохраняют черты, характерные для среднесарматской культурной традиции (ямы подквадратной формы, диагональное положение и южная ориентировка погребенного), что свойственно для междуречья Волги и Дона и неоднократно отмечалось исследователями.

Вторая по численности группа застежек представлена лучковыми фибулами с подвязным приемником. А.К. Амброз разделил фибулы этой группы на четыре серии с последующим членением каждой из них на варианты по степени раскованности ножки, высоте и профилю дужки, датировав фибулы этой серии I-III вв. н. э. [3, с. 48-57]. Эта типологическая схема получила широкое признание в среде археологов и в дальнейшем использовалась ими практически без изменений, чего нельзя сказать о ее хронологических позициях. Первым предложил удревнить дату появления одночленных лучковых подвязных фибул Б.Ю. Михлин, который на основе материалов Беляусского могильника отнес появление фибул этой серии к концу I в. до н. э. [29, c. 205]. В дальнейшем было предложено отнести это событие к концу II - первой половине I в. до н. э. [7, с. 135-136]. К концу II рубежу II-I вв. до н. э. относят появление фибул подвязной конструкции Ю.П. Зайцев и В.И. Мордвинцева [11, с. 151].

А.С. Скрипкиным был выделен «новый вариант» застежек этой серии, отличающийся низкой спинкой с сильным прогибом у пружины, верхней тетивой и практически параллельным расположением спинки и иглы по отношению друг к другу, который он датировал в рамках I в. до н. э. - начала I в. н. э. $[38$, c. 128,133$]$.
Пересматривалась и типология лучковых подвязных фибул. При дальнейших исследованиях и увеличении археологического материала было выявлено, что разные варианты этих застежек могут встречаться в одном погребении $[1$, с. $92 ; 18$, с. 56]. Стройная система смены вариантов, предложенная А.К. Амброзом, стала нуждаться в корректировке. В.М. Косяненко, проведя анализ пропорций бронзовых застежек этой группы, предложила полностью отказаться от схемы А.К. Амброза и считать типообразующим признаком, влияющим на хронологические позиции фибул, не кривизну спинки и раскованность дужки, а длину и сложность обмотки $[18$, с. 54]. В.В. Кропотов, оставив деление на четыре серии, предложенное А.К. Амброзом, указал на необходимость «значительной корректировки» их вариантов [21, с. 68]. Им были выделены четыре варианта проволочных одночленных фибул по тем же признакам, по которым и раньше разрабатывалась их типология (раскованность ножки, высота и изгиб дужки) добавив в эту схему размеры фибул [21, с. 71-80].

Всего на памятниках Есауловского Аксая было обнаружено 7 фибул этого типа: 6 фибул - одночленные застежки разных вариантов; 1 - двучленная фибула с расширенной ножкой.

Одночленная лучковая подвязная фибула с низкой спинкой с прогибом у пружины под прямым углом, пружиной с верхней тетивой и трехвитковой завязкой была найдена в погребении кургана 16 могильника Перегрузное I [22, с. 29, рис. 31, 2]. Длина-4,7 см (рис. 3, 1). Эту застежку А.С. Скрипкин относит к «новому типу», датируя ее I в. до н. э. - началом I в. н. э. [38, с. 133], а В.В. Кропотов эту же фибулу относит ко 2-му варианту I серии своей типологии, который предложил датировать серединой I - началом II в. н. э. [21, с. 74]. Вещевой материал погребения подробно был рассмотрен И.В. Сергацковым и датирован первой половиной I в. н. э. [34].

Бронзовая одночленная фибула с высокой плавно изогнутой дужкой, пластинчатой расширяющейся книзу ножкой и трехвитковой завязкой встречена в погребении кургана 14 Терновского могильника [41, л. 26, рис. 42]. Длина застежки - 6 см (рис. 3,2 ). Фибула это- 
го варианта датируется большинством исследователей в пределах первой половины ІІ в. н. э. $[3$, с. $49 ; 21$, с. $75 ; 39$, с. 107$]$. Вещевой комплекс погребения из кургана 14 может быть датирован в рамках II в. н. э. без возможности установления более узких рамок.

В погребении кургана 3 могильника Абганерово IV найдена одночленная лучковая фибула с высокой круто спускающейся к пружине дужкой, расширенной ножкой и фигурной обмоткой [14, с. 226, рис. 2, 8]. Длина - 6 см (рис. 3, 3). В погребении кургана 5 Чиковского могильника была обнаружена аналогичная фибула с многовитковой обмоткой [44, л. 58, рис. 226]. Длина фибулы - 6,4 см (рис. 3, 4). Застежки этого варианта обычно датируются второй половиной II в. н. э. [3, с. 50; 39, с. 107]. Этим временем может быть датирован и другой материал из данных погребений.

Фибула с высокой нависающей над пружиной дужкой, расширенной ножкой и многовитковой обмоткой встречена в погребении кургана 35 Чиковского могильника [43, л. 46, рис. XXXIX, 4]. Длина - 7,2 см (рис. 3, 5). В погребении кургана 8 Новоаксайского могильника была найдена аналогичная фибула с многовитковой обмоткой [42, л. 4, рис. 12]. Длина фибулы - 7 см (рис. 3, 8) ${ }^{3}$. Застежки этого варианта были отнесены А.К. Амброзом к III в. н. э. [3, с. 51]. А.С. Скрипкин предложил сузить эту дату в рамках первой половины III в. н. э. [39, с. 107]. Вещевой комплекс погребений может быть датирован в пределах первой половины III в. н. э.

В погребении кургана 74 Жутовского могильника была обнаружена деформированная одночленная лучковая подвязная застежка с семивитковой завязкой [25, л. 24]. Длина $-3,5$ см (рис. 3, 6). Деформация застежки серьезно затрудняет ее отнесение к определенному варианту. В.В. Кропотов отнес эту застежку ко 2-му варианту своей типологии, который был им датирован серединой I - началом II в. н. э. [21, с. 74, 91]. Жутовское погребение разграблено и, кроме фибулы, иных вещей в нем не найдено.

В погребении кургана 25 могильника Абганерово II была обнаружена двучленная лучковая фибула с расширенной гладкой ножкой и спинкой из массивного стержня $[15$, с. 87 , рис. 8, 8]. Длина - 6,4 см (рис. 3, 7). Застежки этого типа обычно датируются второй половиной III в. н. э. [39, с. 108], второй половиной III - IV в. н. э. [20, с. 63; 21, с. 151]. Погребение из кургана 25 могильника Абганерово II было ограблено и может быть датировано только по фибуле.

В идентификации остальных фибул существуют значительные трудности. Так, 3 фибулы (Аксай I, к. 3, п. 1; Аксай V, к. 1, п. 2; Аксай V, к. 4, п. 1) представлены невыразительными фрагментами, что не позволяет уверенно отнести их к какой-либо группе. Также не поддается идентификации и фибула из кургана 40 Терновского могильника. Место хранения фибулы неизвестно, в иллюстративном приложении к отчету не даны ни фотография, ни рисунок данной находки, нет подробного описания фибулы и в тексте отчета В.П. Шилова [41, л. 50a]. Трудно отнести к какой-либо группе и фибулу из кургана 1 могильника Антонов I. Так, И.В. Сергацков отнес фибулу к группе «фибул с кнопкой на конце приемника» 2-го варианта (по типологии А.К. Амброза) [33, с. 414], а В.В. Кропотов эту же фибулу причисляет к группе 8 «фибулы с завитком на конце приемника» серии I формы 5 [21, с. 201]. При этом основания для отнесения данной фибулы к какой-либо из этих групп остаются неясными, так как типообразующий признак «завиток» или «кнопка» - на фибуле отсутствует, а кончик приемника был обломан еще в древности [26, л. 18, рис. 43, 4]. Невозможно примирить эти разногласия и в связи с различной датировкой фибул каждой из групп. Так, фибулы с завитком на конце приемника датируется В.В. Кропотовым второй половиной I II в. н. э. с возможным бытованием отдельных экземпляров в первой половине III в. н. э. $[21$, c. 183]. Фибулы с кнопкой на конце приемника, в том числе и фибулу из могильника Антонов, И.В. Сергацков датировал I в. н. э. $[33$, c. 414$]$.

Результаты. Время бытования фибул, обнаруженных в памятниках Есауловского Аксая, можно разделить на два периода. Для первого периода, датируемого I в. до н. э. первой половиной II в. н. э., ассортимент фибул достаточно широк. В это время, вероятно, через городские центры Северного Причерноморья в степь поступают провинциаль- 
но-римские застежки, но, несмотря на большое разнообразие типов фибул в этот период, их количество мало и встречается в $5 \%$ погребений. Во второй период (вторая половина II - первая половина III в. н. э.) отмечается увеличение количества фибул в сарматских погребениях при существенном снижении ассортимента. В это время фибулы представлены всего двумя типами застежек, изготавливаемыми в городах Боспора и встречающимися в $26 \%$ погребений этого времени. В связи с событиями середины III в. н. э. поступление фибул, как и других импортов из Се- верного Причерноморья в степи Есауловского Аксая, прекращается.

\section{ПРИМЕЧАНИЯ}

${ }^{1}$ Статья выполнена в рамках государственного задания Министерства образования и науки РФ, проект № 33.2830.2017/4.6 «Юг России в эпохураннего железного века: диалог культур Восток - Запад».

${ }^{2}$ Выражаю благодарность В.В. Кропотову за рекомендации и ценные советы.

${ }^{3}$ Фибула утеряна, описание приводится по данным отчета. 

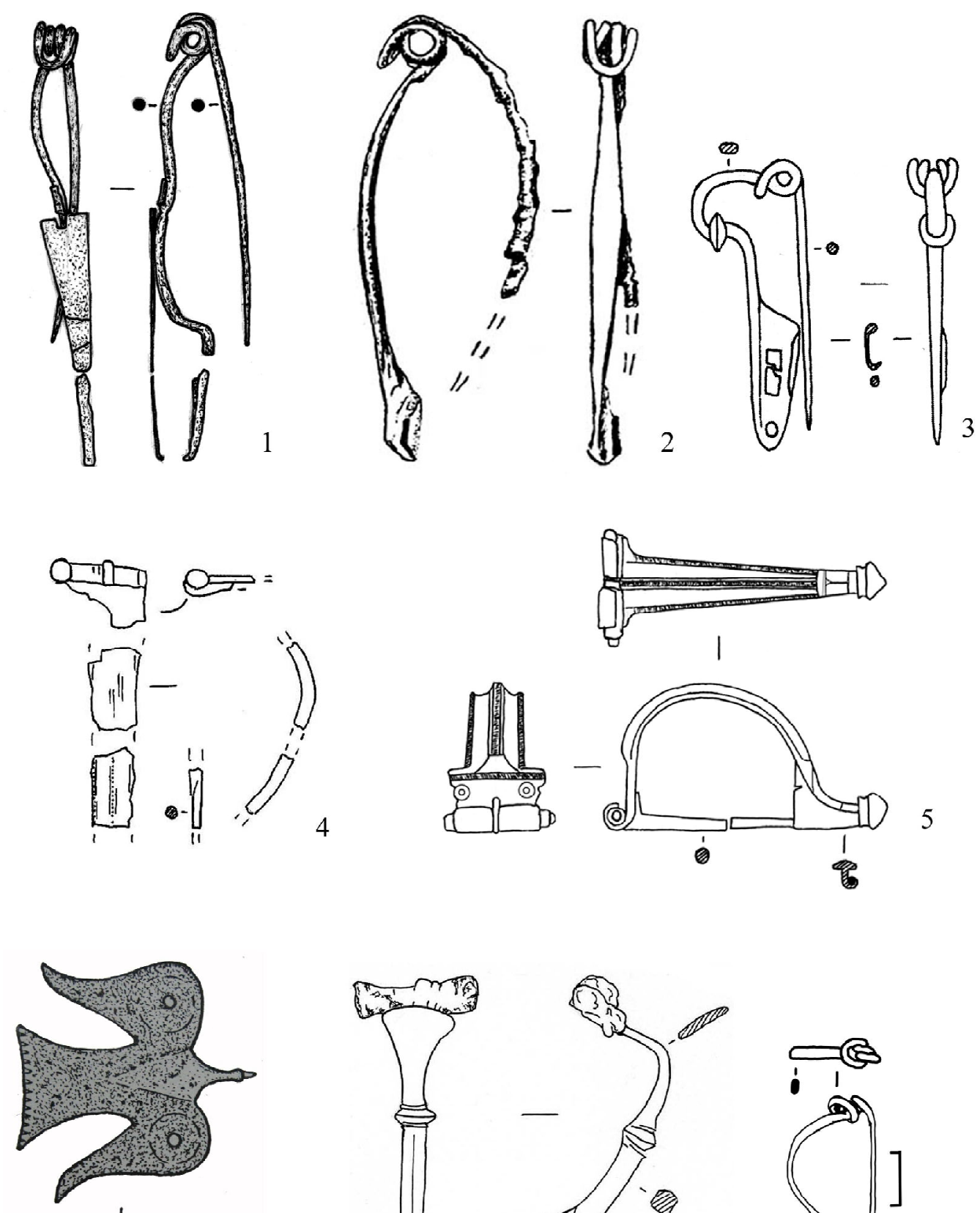

1
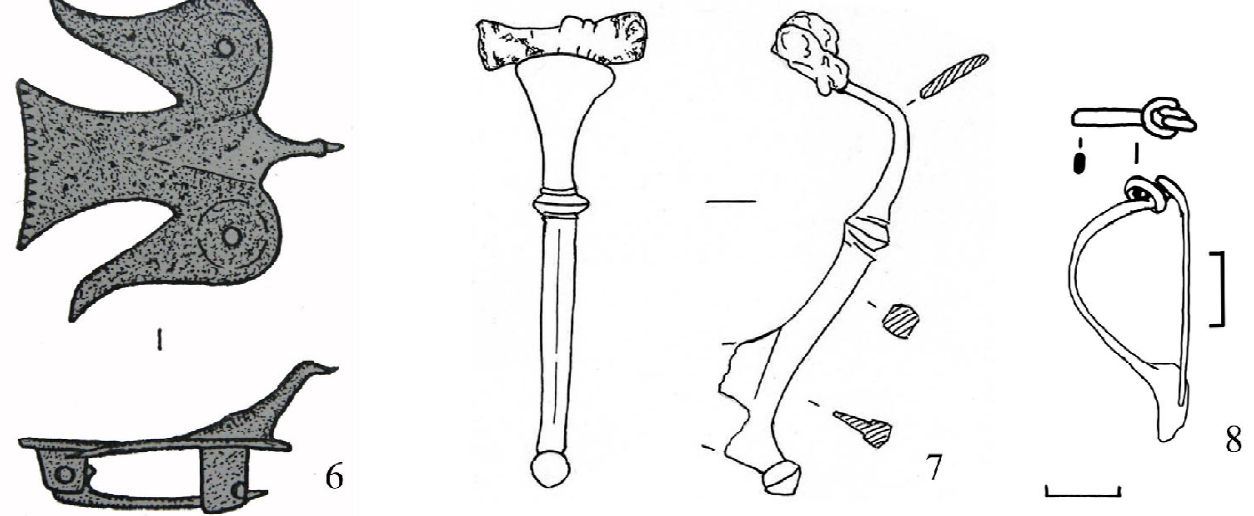

Рис. 1. Фибулы из погребальных комплексов Есауловского Аксая:

1 - Перегрузное I, к. 33, п. 5; 2 - Аксай I, к. 6, п. 1; 3 - Перегрузное I, к. 51, п. 2; 4 - Аксай II, к. 25, п. 1; 5 - Ковалевка, к. 8, п. 2; 6 - Октябрьский II, к. 1, п. 1; 7 - Аксай II, к. 36, п. 1; 8 - Антонов I, к. 1, п. 1

Fig. 1. Fibulae from burial complexes of the Esaulovsky Aksai:

1 - Peregruznoe I, barrow 33, burial 5; 2 - Aksai I, barrow 6, burial 1; 3 - Peregruznoe I, barrow 51, burial 2;

4 - Aksai II, barrow 25, burial 1; 5 - Kovalevka, barrow 8, burial 2; 6 - Oktyabrskiy II, barrow 1, burial 1;

7 - Aksai II, barrow 36, burial 1; 8 - Antonov I, barrow 1, burial 1 


\section{АРХЕОЛОГИЯ}
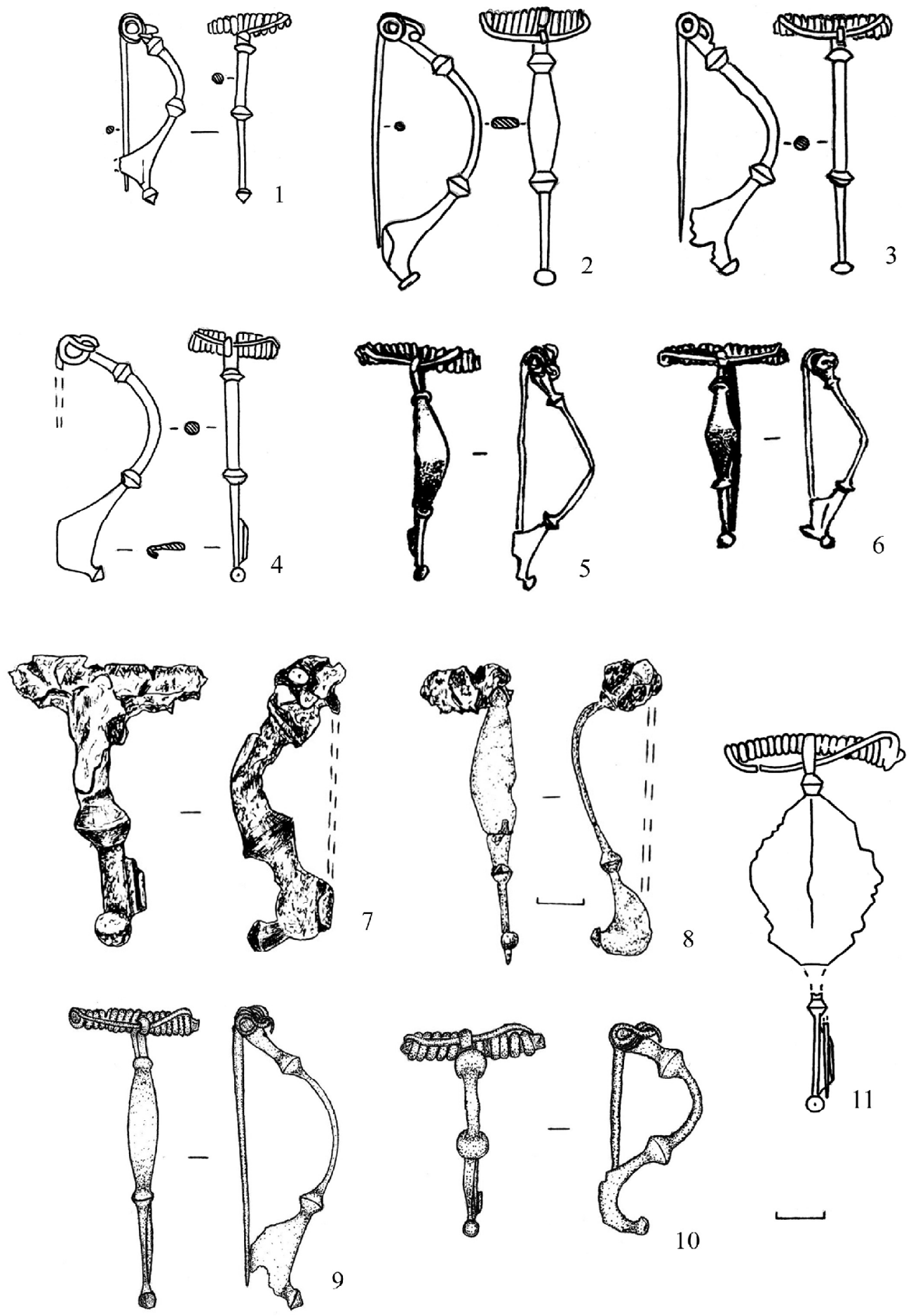

Рис. 2. Сильно профилированные фибулы из погребальных комплексов Есауловского Аксая:

1 - Жутово, к. 2, п. 1; 2 - Жутово, к. 3, п. 1; 3 - Жутово, к. 38, п. 1; 4 - Жутово, к. 56, п. 1;

5 - Аксай I, к. 1, п. 1; 6 - Аксай I, к. 1, п. 1; 7 - Перегрузное I, к. 21, п. 1; 8 - Перегрузное I, к. 21, п. 1;

9 - Перегрузное I, к. 27, п. 1; 10 - Перегрузное I, к. 21, п. 1; 11 - Чиковский, к. 46, п. 1

Fig. 2. Deeply profiled fibulae from burial complexes of the Esaulovsky Aksai:

1 - Zhutovo, barrow 2, burial 1; 2 - Zhutovo, barrow 3, burial 1; 3 - Zhutovo, barrow 38, burial 1;

4 - Zhutovo, barrow 56, burial 1; 5 - Aksai I, barrow 1, burial 1; 6 - Aksai I, barrow 1, burial 1;

7 - Peregruznoe I, barrow 21, burial 1;8 - Peregruznoe I, barrow 21, burial 1; 9 - Peregruznoe I, barrow 27, burial 1; 10 - Peregruznoe I, barrow 21, burial 1; 11 - Chikovskiy, barrow 46, burial 1 

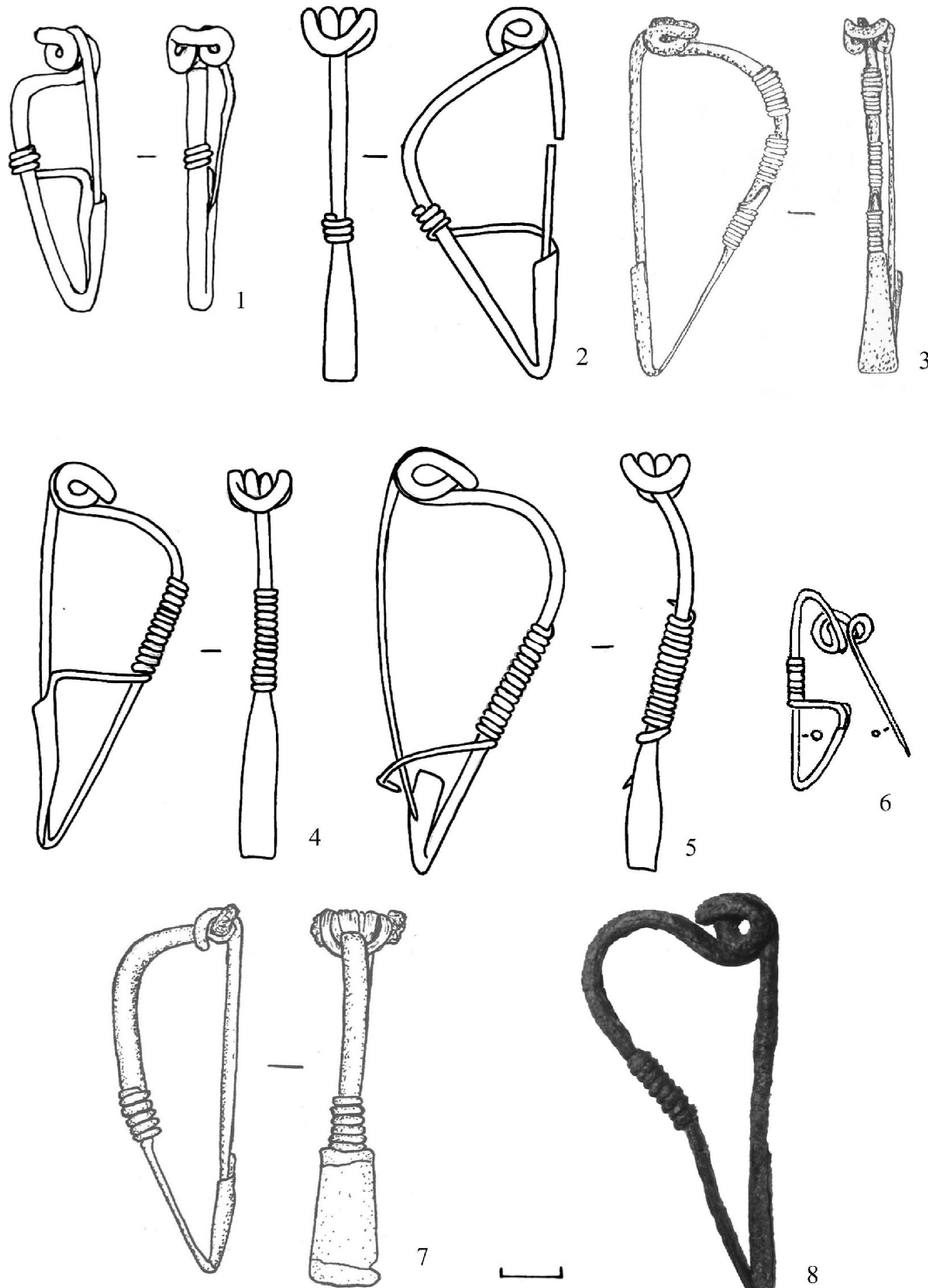

7

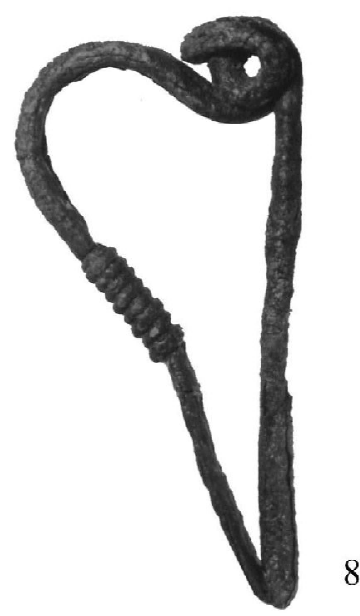

Рис. 3. Лучковые подвязные фибулы из погребальных комплексов Есауловского Аксая:

1 - Перегрузное I, к. 16, п. 1; 2 - Терновский, к. 14, п. 1; 3 - Абганерово IV, к. 3, п. 1; 4 - Чиковский, к. 5, п. 1; 5 - Чиковский, к. 35, п. 1; 6 - Жутово, к. 74, п. 1; 7 - Абганерово II, к. 25, п. 1; 8 - Новоаксайский, к. 8, п. 1

Fig. 3. Bow-shaped undertied fibulae from burial complexes of the Esaulovsky Aksai:

1 - Peregruznoe I, barrow 16, burial 1; 2 - Ternovskiy, barrow 14, burial 1; 3 - Abganerovo IV, barrow 3, burial 1; 4 - Chikovskiy, barrow 5, burial 1; 5 - Chikovskiy, barrow 35, burial 1; 6 - Zhutovo, barrow 74, burial 1;

7 - Abganerovo II, barrow 25, burial 1; 8 - Novoaksayskiy, barrow 8, burial 1 


\section{СПИСОК ЛИТЕРАТУРЫ}

1. Абрамова, М. П. Подкумский могильник / М. П. Абрамова. - М. : Наука, 1987. - 182 с.

2. Абрамова, М. П. Фибулы Хумаринского могильника (II-III вв. н. э.) / М. П. Абрамова // Историко-археологический альманах. - М. ; Армавир : [б. и.], 1996. - № 2. - С. 100-105.

3. Амброз, А. К. Фибулы юга европейской части СССР (II в. до н. э. - IV в. н. э.) / А. К. Амброз. - М. : Наука, 1966. - 142 с. - (Свод археологических источников ; вып. Д1-30).

4. Археологические исследования в ВолгоДонском междуречье / А. Н. Дьяченко [и др.] // Нижневолжский археологический вестник. 1999. - Вып. 2. - С. 93-126.

5. Габуев, Т. А. Памятники ранних алан центральных районов Северного Кавказа / Т. А. Габуев, В. Ю. Малашев. - М. : ИА РАН : ТАУС, 2009. - 468 с.

6. Горбенко, А. А. Некрополь Паниадриса (Крепостного городища) / А. А. Горбенко, В. М. Косяненко // Азовский историко-археологический и палеонтологический музей-заповедник / отв. ред. Е. Н. Самарич. - Азов : Изд-во Азов. музея-заповедника, 2011. - 512 с. - (Донские древности ; вып. 11).

7. Дашевская, О. Д. Четыре комплекса с фибулами из Беляусского могильника / О. Д. Дашевская, Б. Ю. Минлих // Советская археология. - 1983. № 3. - С. 129-147.

8. Дьяченко, А. Н. Отчет о проведении археологических исследований курганных могильников Аксай I и Ковалевка в Октябрьском районе Волгоградской области в 2014 году / А. Н. Дьяченко. - Волгоград, 2015. - 136 с. // Архив ВОКМ. - № 300.

9. Дьяченко, А. Н. Раскопки курганных могильников Аксай II и Аксай III у села Аксай Октябрьского района Волгоградской области (к вопросу об экономических связях сарматского населения Волго-Донского региона) / А. Н. Дьяченко, А. С. Скрипикн, В. И. Моисеев // Материалы по археологии Волго-Донских степей : сб. ст. - Волгоград : Изд-во Волгогр. ин-та упр. - фил. РАНХиГС, 2017. - Вып. 4. - С. 8-82.

10. Зайцев, Ю. П. Варварские погребения Крыма ІІ в. до н. э. - І в. н. э. / Ю. П. Зайцев, В. И. Мордвинцева // Сарматские культуры Евразии: проблемы региональной хронологии : докл. к 5-й Междунар. конф. «Проблемы сарматской археологии и истории» / отв. ред. Б. А. Раев. - Краснодар : [б. и.], 2004.- С. $174-204$.

11. Зайцев, Ю. П. Подвязные фибулы в варварских погребениях Северного Причерноморья позднеэллинистического периода / Ю. П. Зайцев, В. И. Мордвинцева // Российская археология. 2003. - № 2. - С. 135-154.
12. Каспарова, К. В. О верхней хронологической границе зарубенецкой культуры Припятского Полесья / К. В. Каспарова // Советская археология. 1976. - № 3. - C. 128-140.

13. Каспарова, К. В. Роль юго-западных связей в процессе формирования зарубенецкой культуры / К. В. Каспарова // Советская археология. 1981. - № 2. - C. 57-79.

14. Клепиков, В. М. Позднесарматские погребения курганного могильника Абганерово IV / В. М. Клепиков // Материалы по археологии ВолгоДонских степей : сб. науч. ст. - Волгоград : Изд-во ВолГУ, 2001. - Вып. 1.-С. 225-235.

15. Клепиков, В. М. Позднесарматский могильник Абганерово II / В. М. Клепиков, О. А. Шинкарь // Историко-археологические исследования в Нижнем Поволжье : сб. науч. ст. - Волгоград : Изд-во ВолГУ, 1997. -Вып. 2 / отв. ред. Б. Ф. Железчиков. -С. 81-100.

16. Коробкова, Е. А. История изучения археологических памятников бассейна реки Есауловский Аксай / Е. А. Коробкова // Вестник Волгоградского государственного университета. Серия 4, История. Регионоведение. Международные отношения. - 2011. - № 1 (19). - C. 146-154. - DOI: http:// doi.org/10.15688/jvolsu4.2011.1.21.

17. Костромичёв, Д. А. Римские фибулы Херсонеса / Д. А. Костромичёв // Херсонесский сборник : сб. науч. ст. - Севастополь : Арефьев М.Э., 2012. - Вып. 17. - С. 47-154.

18. Косяненко, В. М. Бронзовые фибулы из некрополя Кобякова городища / В. М. Косяненко // Советская археология. - 1987. - № 2. - С. 45-62.

19. Косяненко, В. М. Некрополь Кобякова городища (по материалам раскопок 1956-1962 гг.) / В. М. Косяненко // Азовский историко-археологический и палеонтологический музей-заповедник. - Азов : Изд-во Азов. музея-заповедника, 2008. - 544 с. - (Донские древности ; вып. 9).

20. Кривошеев, М. В. Позднесарматская культура южной части междуречья Волги и Дона. Проблемы хронологии и периодизации : дис. ... канд. ист. наук : 07.00.06 / Кривошеев Михаил Васильевич. - Волгоград, 2005. - 336 с. : ил.

21. Кропотов, В. В. Фибулы сарматской эпохи / В. В. Кропотов. - Киев : АДЕФ -Украина, 2010. $384 \mathrm{c}$.

22. Курганный могильник Перегрузное I: peзультаты междисциплинарных исследований : монография / М. А. Балабанова [и др.]. - Волгоград : Изд-во Волгогр. филиала РАНХиГС, 2014. - 360 с.

23. Лимберис, Н. Ю. Римские и провинциально-римские бронзовые фибулы из Прикубанья / Н. Ю. Лимберис, И. И. Марченко // Материалы и исследования по истории Кубани : сб. науч. тр. / отв. ред. И. И. Марченко. - Краснодар : НСС, 2004. С. 221-241. 
24. Маловицкая, Л. Я. Отчет о работах Астраханской экспедиции в 1965 г. / Л. Я. Маловицкая // Архив ИА РАН. - Р-1. - № 3429, 3429а, 3429б. - 39 л.

25. Мамонтов, В. И. Отчет о работе Приволжского отряда Волго-Донской экспедиции ЛОИА АН СССР и Волгоградского Областного отделения ВООПИК в Волгоградской области (Калачевский, Октябрьский, Суровикинский, Средне-Ахтубинский, Иловлинский р-ны) за сезон 1974 г. - Волгоград, 1975 // Архив ВОКМ. - № 33. - 53 л.

26. Мамонтов, В. И. Отчет о работе Приволжского отряда ЛОИА АН СССР и Донской экспедиции Волгоградского пединститута в 1991 году / В. И. Мамонтов // Архив ВОКМ. - № 106. - 66 л.

27. Масякин, В. В. Римские фибулы и детали ременной гарнитуры из некрополя Заветное / В. В. Масякин // Древняя Таврика. Посвящается 80-летию Татьяны Николаевны Высотской : сб. науч. работ / под общ. ред. Ю. П. Зайцева, В. И. Мордвинцевой. - Симферополь : Универсум, 2007.-- С. 125-138.

28. Михлин, Б. Ю. Сарматское погребение в Южном Донбассе / Б. Ю. Минлих // Советская археология. - 1975. - № 4. - С. 185-192.

29. Михлин, Б. Ю. Фибулы Беляусского могильника / Б. Ю. Минлих // Советская археология. 1980. - № 3. - С. 194-231.

30. Мордвинцева, В. И. Курганы сарматской знати у поселка Октябрьский / В. И. Мордвинцева, Е. П. Мыськов // Археологические вести. - 1999. № 6. - C. 179-191.

31. Мошкова, М. Г. Фибулы из позднесарматских погребений Южного Приуралья: вопросы хронологии и производства / М. Г. Мошкова // Нижневолжский археологический вестник. - 2000. Вып. 3. -С. 186-200.

32. Пачкова, С. П. Зарубинецкая культура и латенизированные культуры Европы / С. П. Пачкова. - Киев : КОРВШ Пресс, 2006. - 372 с., 172 ил.

33. Сергацков, И. В. Фибулы из погребений Азиатской Сарматии I - первой половины II в. н. э. / И. В. Сергацков // Северный Кавказ и мир кочевников в раннем железном веке : сб. памяти М.П. Абрамовой. -М. : ИАРАН: ТАУС, 2007.-С. 408-431.-(Материалы и исследования по археологии России ; № 8).

34. Сергацков, И. В. Материалы к хронологии раннего варианта лучковых фибул / И. В. Сергацков // Нижневолжский археологический вестник. 2009. - Вып. 10. - С. 251-259.

35. Симоненко, А. В. Римский импорт у сарматов Северного Причерноморья / А. В. Симоненко. - СПб. : Филол. фак. СПбГУ ; Нестор-История, 2011.-272 c.

36. Скрипкин, А. С. Азиатская Сарматия. Проблемы хронологии и ее исторический аспект / А. С. Скрипкин. - Саратов : Изд-во Сарат. ун-та, 1990. $-300 \mathrm{c}$.
37. Скрипкин, А. С. [Рецензия] / А. С. Скрипкин // Российская археология. - 2014. - № 1. - С. 182 186. - Рец. на кн.: Кропотов, В. В. Фибулы сарматской эпохи / В. В. Кропотов. - Киев : АДЕФ -Украина, 2010. - 384 с., 105 ил.

38. Скрипкин, А. С. О новом варианте лучковых фибул из сарматских погребений в Волго-Донском междуречье / А. С. Скрипкин // Российская археология. - 2003. - № 2. - С. 128-134.

39. Скрипкин, А. С. Фибулы Нижнего Поволжья (по материалам сарматских погребений) / А. С. Скрипкин // Советская археология. - 1977. № 2. - C. 100-120.

40. Шилов, В. П. Отчет о работах Астраханской экспедиции за 1964 г. / В. П. Шилов // Архив ИА РАН. - Р-1. - № 3156, 3156а. - 136 л.

41. Шилов, В. П. Отчет о работах Астраханской экспедиции за 1966 г. / В. П. Шилов // Архив ИА РАН. - Р-1. - № 4625, 4625a. - 110 л.

42. Шилов, В. П. Отчет о раскопках Волго-Донской археологической экспедиции ЛОИА АН СССР в 1975 г. / В. П. Шилов // Архив ИА РАН. - Р-1. № 6470, 6470а. - 29 л.

43. Шилов, В. П. Отчет о раскопках Волго-Донской археологической экспедиции в 1977 г. / В. П. Шилов // Архив ИА РАН. - Р-1. - № 9530, 9530а. - 61 л.

44. Шилов, В. П. Отчет о раскопках Волго-Донской экспедиции в 1976 г. / В. П. Шилов, К. С. Лагоцкий // Архив ИА РАН. - Р-1. - № 6295, 6295а. - 59 л.

45. Almgren, O. Studien über nordeuropäischen Fibelformen der ersten nachhristischen Jarhunderte mit Berücksichtigung der prowinzialrömischen und südrussischen Formen / O. Almgren. - Leipzig : Verl. von Curt Kabitzsch, 1923. - 254 S.

46. Cociş, S. Fibulele din Dacia romană / S. Cociş. Cluj-Napoca : [s. n.], 2004. -454 š.

47. Ettlinger, E. Dierömischen Fibeln in der Schweiz /E. Ettlinger. - Bern : A. Francke Verl., 1973.-205 S.

48. Feugère, M. Les fibules en Gaule Méridionale de la conquête à la fin du Ve s.ap. J.-C. / M. Feugère.-Paris : Ed. CNRS, 1985.-509 p. -(Revue archéologique de Narbonnaise ; t. 12).

49. Riha, E. Die römischen Fibeln aus Augst und Kaiseraugst / E. Riha. - Augst : Amt für Museen und Archäologie des Kantons Basel-Landschaft, 1979. 206 S. - (Forschungen in Augst ; Bd. 3).

50. Rustoiu, A. Fibulele din Dacia preromană (sec. II î. E.n. - I e.n.) / A. Rustoiu. - Bucureşti : [s. n.], 1997. $-238 \mathrm{p}$.

\section{REFERENCES}

1. Abramova M.P. Podkumskiy mogilnik [Podkumsky Burial Ground]. Moscow, Nauka Publ., 1987. $182 \mathrm{p}$. 
2. Abramova M.P. Fibuly Khumarinskogo mogilnika (II-III vv. n.e.) [Fibulae of the Khumarian Burial Ground $\left(2^{\text {nd }}-3^{\text {rd }}\right.$ cent. AD) $]$. Istorikoarkheologicheskiy almanakh. Moscow; Armavir, 1996, no. 2, pp. 100-105.

3. Ambroz A.K. Fibuly yuga evropeyskoy chasti SSSR (II v. do n.e. -IV v. n.e.) [Fibulae from the Southern European Part of the USSR $\left(2^{\text {nd }}\right.$ cent. BC $4^{\text {th }}$ cent. AD)]. Moscow, Nauka Publ., 1966. 113 p.

4. Dyachenko A.N., Meyb E., Skripkin A.S., Klepikov V.M. Arkheologicheskie issledovaniya v Volgo-Donskom mezhdurechye [Archaeological Research in the Volga-Don Interfluve]. Nizhnevolzhskiy arkheologicheskiy vestnik [The Lower Volga Archaeological Bulletin], 1999, iss. 2, pp. 93-126.

5. Gabuev T.A., Malashev V.Yu. Pamyatniki rannikh alan tsentralnykh rayongov Severnogo Kavkaza [Monuments of the Early Alans of the Central Regions of the North Caucasus]. Moscow, IA RAN; TAUS Publ., 2009. 468 p.

6. Gorbenko A.A., Kosyanenko V.M. Nekropol Paniadrisa (Krepostnogo gorodishcha) [Necropolis Paniadris (Fortress Settlement)]. Samarich E.N., ed. Azovskiy istoriko-arkheologicheskiy i paleontologicheskiy muzey-zapovednik. Azov, Izd-vo Azovskogo muzeya-zapovednika, 2011. 512 p. (Donskie drevnosti; iss. 11).

7. Dashevskaya O.D., Minlikh B.Yu. Chetyre kompleksa s fibulami iz Belyausskogo mogilnika [Four Complexes with Fibulae from the Belyaussky Burial Ground]. Sovetskaya arkheologiya, 1983, no. 3, pp. 129-147.

8. Dyachenko A.N. Otchet o provedenii arkheologicheskikh issledovaniy kurgannykh mogilnikov Aksay I i Kovalevka v Oktyabrskom rayone Volgogradskoy oblasti v 2014 godu. Volgograd, 2015. 136 s. [Report on the Archaeological Research of the Burial Mounds Aksai I and Kovalevka in the Oktyabrsky District of the Volgograd region in 2014. Volgograd, 2015. 136 p.]. Arhiv VOKM, no. 300.

9. Dyachenko A.N., Skripikn A.S., Moiseev V.I. Raskopki kurgannykh mogilnikov Aksay II i Aksay III u sela Aksay Oktyabrskogo rayona Volgogradskoy oblasti (k voprosu ob ekonomicheskikh svyazyakh sarmatskogo naseleniya Volgo-Donskogo regiona) [Excavations of the Burial Mounds Aksai II and Aksai III near the Village of Aksai of the Oktyabrsky District of the Volgograd Region (on the Economic Ties between the Sarmatian Population of the Volga-Don Region)]. Materialy po arkheologii Volgo-Donskikh stepey: sbornik statey. Volgograd, Izd-vo RANKhiGS, 2017, iss. 4, pp. 8-82

10. Zaytsev Yu.P., Mordvintseva V.I. Varvarskie pogrebeniya Kryma II v. do n.e. - I v. n.e. [Barbaric Burials of Crimea in the $\left.2^{\text {nd }} c . B C-1^{\text {st }} c . A D\right]$. Raev B.A., ed. Sarmatskie kultury Evrazii: problemy regionalnoy khronologii: Doklady $k 5$ Mezhdunarodnoy konferentsii «Problemy sarmatskoy arkheologii i istorii». Krasnodar, 2004, pp. 174-204.

11. Zaytsev Yu.P., Mordvintseva V.I. Podvyaznye fibuly v varvarskikh pogrebeniyakh Severnogo Prichernomorya pozdneellinisticheskogo perioda [Subbelt Fibulae in the Barbarian Burials of the Northern Black Sea Region of the Late Hellenistic Period]. Rossiyskaya arkheologiya, 2003, no. 2, pp. 135-154.

12. Kasparova K.V. O verkhneykhronologicheskoy granitse zarubenetskoy kultury Pripyatskogo Polesya [On the Upper Chronological Border of the Zarubenets Culture of the Pripyatskoe Polesye]. Sovetskaya arkheologiya, 1976, no. 3, pp. 128-140.

13. Kasparova K.V. Rol yugo-zapadnykh svyazey $\mathrm{v}$ protsesse formirovaniya zarubenetskoy kultury [The Role of South-West Relations in the Process of the Zarubenets Culture Formation]. Sovetskaya arkheologiya, 1981, no. 2, pp. 57-79.

14. Klepikov V.M. Pozdnesarmatskie pogrebeniya kurgannogo mogilnika Abganerovo IV [Late Sarmatian Burials of the Abganerovo IV Burial Mound]. Materialy po arkheologii Volgo-Donskikh stepey: sbornik nauchnykh statey. Volgograd, Izd-vo VolGU, 2001, iss. 1, pp. 225-235.

15. Klepikov V.M., Shinkar O.A. Pozdnesarmatskiy mogilnik Abganerovo II [Late Sarmatian Burial Ground Abganerovo II]. Istoriko-arkheologicheskie issledovaniya v Nizhnem Povolzhye: sbornik nauchnykh statey. Volgograd, Izd-vo VolGU, 1997, iss. 2, pp. 81-100.

16. Korobkova E.A. Istoriya izucheniya arkheologicheskikh pamyatnikov basseyna reki Esaulovskiy Aksay [Studying Archeological Monuments in the Basin of Esaulovsky Aksai River]. Vestnik Volgogradskogo gosudarstvennogo universiteta. Seriya 4, Istoriya. Regionovedenie. Mezhdunarodnye otnosheniya [Science Journal of Volgograd State University. History. Area Studies. International Relations], 2011, no. 1, pp. 146-154. DOI: http://doi.org/10.15688/jvolsu4.2011.1.21.

17. Kostromichev D.A. Rimskie fibuly Khersonesa [Roman Fibulae of Chersonesos]. Khersonesskiy sbornik. Sevastopol, Arefyev M.E. Publ., 2012, iss. 17, pp. 47-154.

18. Kosyanenko V.M. Bronzovye fibuly iz nekropolya Kobyakova gorodishcha [Bronze Fibulae from the Necropolis of the Kobyak Site]. Sovetskaya arkheologiya, 1987, no. 2, pp. 45-62.

19. Kosyanenko V.M. Nekropol Kobyakova gorodishcha (po materialam raskopok 1956-1962 gg.) [Necropolis of the Kobyak Site (Based on the Materials of Excavations of 1956-1962)]. Azovskiy istorikoarkheologicheskiy i paleontologicheskiy muzey- 
zapovednik. Azov, Izd-vo Azovskogo muzeyazapovednika, 2008. 544 p. (Donskie drevnosti; iss. 9).

20. Krivosheev M.V. Pozdnesarmatskaya kultura yuzhnoy chasti mezhdurechya Volgi i Dona. Problemy khronologii i periodizatsii: dis. ... kand. ist. nauk [Late Sarmatian Culture of Southern Part of the Volga-Don Interfluve. Problems of Chronology and Periodization. Cand. hist. sci. diss.]. Volgograd, 2005. 336 p.

21. Kropotov V.V. Fibuly sarmatskoy epokhi [Fibulae of the Sarmatian Epoch]. Kiev, ADEF-Ukraina Publ., 2010. 384 p.

22. Balabanova M.A., et al. Kurgannyy mogilnik Peregruznoe I: rezultaty mezhdistsiplinarnykh issledovaniy: monografiya [The Burial Mound Peregruznoe I: Results of Interdisciplinary Research. Monograph]. Volgograd, Izd-vo RANKhiGS, 2014. 360 p.

23. Limberis N.Yu., Marchenko I.I. Rimskie i provintsialno-rimskie bronzovye fibuly iz Prikubanya [Roman and Provincial-Roman Bronze Fibulae from Kuban]. Materialy i issledovaniya po istorii Kubani: sbornik nauchnykh trudov. Krasnodar, NSS Publ., 2004, pp. 221-241.

24. Malovitskaya L. Ya. Otchet o rabotakh Astrakhanskoy ekspeditsii v $1965 \mathrm{~g}$ [Report on the Work of the Astrakhan Expedition in 1965]. Arkhiv IA $R A N, \mathrm{R}-1$, no. 3429, 3429a, 3429b. 39 p.

25. Mamontov V.I. Otchet o rabote Privolzhskogo otryada Volgo-Donskoy ekspeditsii LOIA AN SSSR i Volgogradskogo Oblastnogo otdeleniya VOOPIK v Volgogradskoy oblasti (Kalachevskiy, Oktyabrskiy, Surovikinskiy, Sredne-Akhtubinskiy, Ilovlinskiy r-ny) za sezon 1974 g. Volgograd, 1975 [Report on the Work of the Volga Group of the Volga-Don Expedition of Academy of Sciences of the USSR and the Volgograd Regional Branch VOOPIK in the Volgograd Region (Kalachevsky, Octyabrsky, Surovikinsky, SredneAkhtubinsky, Ilovlinsky Districts) for the Season of 1974. Volgograd, 1975]. Arkhiv VOKM, no. 33. 53 L.

26. Mamontov V.I. Otchet o rabote Privolzhskogo otryada LOIA AN SSSR i Donskoy ekspeditsii Volgogradskogo pedinstituta v 1991 godu [Report on the Work of the Volga Group of Academy of Sciences of the USSR and the Don Expedition of the Volgograd Pedagogical Institute in 1991]. Arkhiv VOKM, no. 106. $66 \mathrm{~L}$.

27. Masyakin V.V. Rimskie fibuly i detali remennoy garnitury iz nekropolya Zavetnoe [Roman Fibulae and Belt Headset Details from the Necropolis of the Covenant]. Zaytsev Yu.P., Mordvintseva V.I., eds. Drevnyaya Tavrika. Posvyashchaetsya 80-letiyu Tatyany Nikolaevny Vysotskoy: sb. nauch. rabot. Simferopol, Universum Publ., 2007, pp. 125-138.

28. Minlikh B.Yu. Sarmatskoe pogrebenie v Yuzhnom Donbasse [Sarmatian Burial in the Southern Donbass]. Sovetskaya arkheologiya, 1975, no. 4, pp. 185-192.
29. Minlikh B.Yu. Fibuly Belyausskogo mogilnika [Fibulae of the Belyaussky Burial Ground]. Sovetskaya arheologiya, 1980, no. 3, pp. 194-231.

30. Mordvintseva V.I., Myskov E.P. Kurgany sarmatskoy znati u poselka Oktyabrskiy [Mounds of Sarmatian Nobility near the Village Oktyabrsky]. Arkheologicheskie vesti, 1999, no. 6, pp. 179-191.

31. Moshkova M.G. Fibuly iz pozdnesarmatskikh pogrebeniy Yuzhnogo Priuralya: voprosy khronologii i proizvodstva [Fibulae from the Late Sarmatian Burials of the Southern Urals: Issues of Chronology and Production]. Nizhnevolzhskiy arkheologicheskiy vestnik [Lower Volga Archaeological Bulletin], 2000, iss. 3, pp. 186-200.

32. Pachkova S.P. Zarubinetskaya kultura $i$ latenizirovannye kultury Evropy [Zarubinets Culture and Latent Cultures of Europe]. Kiev, KORVSh Press, 2006. 372 p., 172 ill.

33. Sergatskov I.V. Fibuly iz pogrebeniy Aziatskoy Sarmatii I - pervoy poloviny II v. n.e. [Fibulae from Asian Sarmatian Burials of the $1^{\text {st }}-$ First Half of the $2^{\text {nd }}$ cc. BC]. Severnyy Kavkaz $i$ mir kochevnikov $v$ rannem zheleznom veke: sb. pamyati M.P. Abramovoy. Moscow, Izd-vo IA RAN, 2007, pp. 408-431. (Materialy i issledovaniya po arkheologii Rossii; no. 8).

34. Sergatskov I.V. Materialy k khronologii rannego varianta luchkovykh fibul [Materials to the Chronology of the Early Version of Arched Fibulae]. Nizhnevolzhskiy arkheologicheskiy vestnik [Lower Volga Archaeological Bulletin], 2009, iss. 10, pp. 251-259.

35. Simonenko A.V. Rimskiy import u sarmatov Severnogo Prichernomorya [Roman Imports from the Sarmatians of the Northern Black Sea Region]. Saint Petersburg, Nestor-Istoriya Publ., 2011. 272 p.

36. Skripkin A.S. Aziatskaya Sarmatiya. Problemy khronologii i ee istoricheskiy aspekt [Asian Sarmatia. Problems of Chronology and Its Historical Aspect]. Saratov, Izd-vo SGU, 1990. 300 p.

37. Skripkin A.S. Review. Rossiyskaya arkheologiya, 2014, no. 1, pp. 182-186. Book Review: Kropotov V.V. Fibuly sarmatskoy epokhi [Fibulae of the Sarmatian Era]. Kiev, ADEF-Ukraina Publ., 2010. 384 p., 105 ill.

38. Skripkin A.S. O novom variante luchkovykh fibul iz sarmatskikh pogrebeniy v Volgo-Donskom mezhdurechye [On a New Variant of Arched Fibulae from Sarmatian Burials in the Volga-Don Interfluve]. Rossiyskaya arkheologiya, 2003, no. 2, pp. 128-134.

39. Skripkin A.S. Fibuly Nizhnego Povolzhya (po materialam sarmatskikh pogrebeniy) [Fibulae of the Lower Volga Region (Based on Materials from Sarmatian Burials)]. Sovetskaya arkheologiya, 1977, no. 2, pp. 100-120.

40. Shilov V.P. Otchet o rabotakh Astrakhanskoy ekspeditsii za 1964 g. [Report on the Works of the 
Astrakhan Expedition for 1964]. Arkhiv IA RAN, R-1, nos 3156, 3156a. $136 \mathrm{p}$.

41. Shilov V.P. Otchet o rabotakh Astrakhanskoy ekspeditsii za $1966 \mathrm{~g}$. [Report on the Works of the Astrakhan Expedition for 1966]. Arkhiv IA RAN, R-1, nos 4625, 4625a. $110 \mathrm{~L}$.

42. Shilov V.P. Otchet o raskopkakh VolgoDonskoy arkheologicheskoy ekspeditsii LOIA AN SSSR v 1975 g. [Report on the Excavations of the VolgaDon Archaeological Expedition of the Academy of Sciences of the USSR in 1975]. Arkhiv IA RAN, R-1, nos 6470, 6470a. 29 L.

43. Shilov V.P. Otchet o raskopkakh VolgoDonskoy arkheologicheskoy ekspeditsii v 1977 g. [Report on the Excavations of the Volga-Don Archaeological Expedition in 1977]. Arkhiv IA RAN, R-1, nos 9530, 9530a. 61 L.

44. Shilov V.P., Lagotskiy K.S. Otchet o raskopkakh Volgo-Donskoy ekspeditsii v 1976 g. [Report on the Excavations of the Volga-Don
Expedition in 1976]. Arkhiv IA RAN, R-1, nos 6295, 6295a. 59 L.

45. Almgren O. Studien über nordeuropäischen Fibelformen der ersten nachhristischen Jarhunderte mit Berücksichtigung der prowinzialrömischen und südrussischen Formen. Leipzig, Verl. von Curt Kabitzsch, $1923.254 \mathrm{p}$.

46. Cociş S. Fibulele din Dacia romană. ClujNapoca, 2004. 454 p.

47. Ettlinger E. Die römischen Fibeln in der Schweiz. Bern, A. Francke Verl., 1973. 205 p.

48. Feugère M. Les fibules en Gaule Méridionale de la conquête à la fin du Ve s.ap. J.-C. Paris, Ed. CNRS, 1985. 509 p. (Revue archéologique de Narbonnaise; vol. 12).

49. Riha E. Die römischen Fibeln aus Augst und Kaiseraugst. Augst, Amt für Museen und Archäologie des Kantons Basel-Landschaft, 1979. 206 p. (Forschungen in Augst; vol. 3).

50. Rustoiu A. Fibulele din Dacia preromană (sec. II î. E.n. - I e.n.). Bucureşti, 1997. 238 p.

\section{Information about the Author}

Elena A. Korobkova, Assistant Professor, Department of Russian and World History, Archaeology, Volgograd State University, Prosp. Universitetsky, 100, 400062 Volgograd, Russian Federation, elena.korobkova@volsu.ru, http://orcid.org/0000-0001-9742-8000

\section{Информация об авторе}

Елена Алексеевна Коробкова, старший преподаватель кафедры отечественной и всеобщей истории, археологии, Волгоградский государственный университет, просп. Университетский, 100, 400062 г. Волгоград, Российская Федерация, elena.korobkova@volsu.ru, http://orcid.org/00000001-9742-8000 